\title{
Effect on Production of Replacing Dietary Starch with Sucrose in Lactating Dairy Cows ${ }^{1}$
}

\author{
G. A. Broderick, ${ }^{2}$ N. D. Luchini, $\dagger^{3}$ S. M. Reynal,$\neq^{4}$ G. A. Varga, $\S$ and V. A. Ishler \\ *Agricultural Research Service, USDA, US Dairy Forage Research Center, 1925 Linden Drive West, Madison, Wisconsin 53706 \\ †Conti-Group Inc., 745 Riverside Drive, Chicago, IL 60606 \\ ‡Department of Dairy Science, University of Wisconsin, Madison 53706 \\ §Animal Science Department, Pennsylvania State University, University Park 16802
}

\begin{abstract}
Replacing dietary starch with sugar has been reported to improve production in dairy cows. Two sets of 24 Holstein cows averaging $41 \mathrm{~kg} / \mathrm{d}$ of milk were fed a covariate diet, blocked by days in milk, and randomly assigned in 2 phases to 4 groups of 6 cows each. Cows were fed experimental diets containing [dry matter (DM) basis]: $39 \%$ alfalfa silage, $21 \%$ corn silage, $21 \%$ rolled high-moisture shelled corn, $9 \%$ soybean meal, $2 \%$ fat, $1 \%$ vitamin-mineral supplement, $7.5 \%$ supplemental nonstructural carbohydrate, $16.7 \%$ crude protein, and $30 \%$ neutral detergent fiber. Nonstructural carbohydrates added to the 4 diets were 1) $7.5 \%$ corn starch, $0 \%$ sucrose; 2) $5.0 \%$ starch, $2.5 \%$ sucrose; 3$) 2.5 \%$ starch, $5.0 \%$ sucrose; or 4) $0 \%$ starch, $7.5 \%$ sucrose. Cows were fed the experimental diets for 8 wk. There were linear increases in DM intake and milk fat content and yield, and linear decreases in ruminal concentrations of ammonia and branched-chain volatile fatty acids, and urinary excretion of urea- $\mathrm{N}$ and total $\mathrm{N}$, and urinary urea- $\mathrm{N}$ as a proportion of total $\mathrm{N}$, as sucrose replaced corn starch in the diet. Despite these changes, there was no effect of diet on microbial protein formation, estimated from total purine flow at the omasum or purine derivative excretion in the urine, and there were linear decreases in both milk/DM intake and milk $\mathrm{N} / \mathrm{N}$-intake when sucrose replaced dietary starch. However, expressing efficiency as fat-corrected milk/DM intake or solids-corrected milk/DM intake indicated that there was no effect of sucrose addition on nutrient utilization. Replacing dietary starch with sucrose increased fat secretion, apparently via increased energy
\end{abstract}

Received June 24, 2008.

Accepted August 26, 2008.

${ }^{1}$ Mention of any trademark or proprietary product in this paper does not constitute a guarantee or warranty of the product by the USDA or the Agricultural Research Service and does not imply its approval to the exclusion of other products that also may be suitable.

${ }^{2}$ Corresponding author: glen.broderick@ars.usda.gov

${ }^{3}$ Current address: Adisseo USA Inc., 1508 Culpepper Dr., Naperville, IL 60540 .

${ }^{4}$ Deceased June 25, 2007. supply because of greater intake. Positive responses normally correlated with improved ruminal $\mathrm{N}$ efficiency that were altered by sucrose feeding were not associated with increased protein secretion in this trial.

Key words: alfalfa silage, nonstructural carbohydrate, sucrose, starch

\section{INTRODUCTION}

Diets based on alfalfa silage and most other hay-crop silages contain high levels of NPN and other sources of RDP (Muck, 1987; McDonald et al., 1991). When such diets are fed, the rate of ruminal energy fermentation may be too slow to allow ruminal organisms to synthesize protein from the rapidly available RDP (Kim et al., 1999a). Under these circumstances, increasing the rate of carbohydrate fermentation could result in more effective capture of RDP and improved supply of MP to the dairy cow. There is in vitro evidence of enhanced net yield of ruminal microbial protein from sugar fermentation (Stokes et al., 1991). Sugars were more rapidly fermented in the rumen than starch (Chamberlain et al., 1993), confirming their effectiveness as supplements for alfalfa silage diets. The Cornell Net Carbohydrate and Protein System (e.g., NRC, 1996) indicated that the organisms fermenting soluble sugars could contribute approximately $18 \%$ more microbial protein than those fermenting the starches in high-moisture corn. Our objective was to assess whether it was advantageous for the lactating dairy cow to increase dietary sugar content. Therefore, we formulated an alfalfa silage-based control diet containing a large amount of corn starch and assessed the effect on production and ruminal metabolism of incremental replacement of the starch with sucrose.

\section{MATERIALS AND METHODS}

\section{Lactation Trial}

Two sets of 24 multiparous Holstein cows, with mean (SD) parity $3.2(1.4), 641$ (58) kg of BW, 77 (53) DIM, 
Table 1. Composition of major dietary ingredients ${ }^{1}$

\begin{tabular}{lcccc}
\hline Component & Alfalfa silage & Corn silage & HMSC & SSBM \\
\hline DM, \% & 42.0 & 33.3 & 73.2 & 89.9 \\
CP, \% of DM & 21.9 & 8.5 & 8.3 & 54.7 \\
Ash, \% of DM & 9.8 & 4.6 & 1.3 & 7.0 \\
NDF, \% of DM & 42.5 & 43.8 & 7.9 & 7.4 \\
ADF, \% of DM & 33.8 & 24.9 & 2.0 & 4.0 \\
pH & 4.6 & 4.0 & 3.9 & - \\
NPN, \% of total N & 63.2 & 53.4 & 49.4 & - \\
Ammonia-N, \% of total N & 10.0 & 3.7 & 7.4 & - \\
Total AA-N, \% of total N & 26.5 & 22.0 & 19.9 & - \\
Unidentified-N, \% of total N & 26.6 & 27.3 & 22.1 & 1.0 \\
ADIN, \% of total N & 3.0 & 1.5 & 4.2 & \\
\hline
\end{tabular}

${ }^{1} \mathrm{HMSC}=$ high-moisture shelled corn; SSBM = solvent-extracted soybean meal.

and 41 (4) $\mathrm{kg}$ milk/d, were blocked within sets into 6 groups of 4 by DIM in a feeding trial of randomized complete block design. The first set of 24 cows was used during phase 1 and the second set was used during phase 2 of the trial. Before starting each experimental phase, all cows were fed the same diet for a 2 -wk covariate period, and production of milk and milk components was determined for use in statistical analyses. Cows within blocks were then randomly assigned to 1 of the 4 diets and fed only that diet during each 8-wk experimental phase. Care and handling of all experimental animals, including ruminal cannulation of cows used in the ruminal metabolism study, was conducted under protocols approved by the University of Wisconsin Institutional Animal Care and Use Committee.

Forage was from the same source of alfalfa silage and corn silage in all diets. The alfalfa silage was harvested using a conventional mower conditioner, field wilted to about $40 \%$ DM, chopped to a theoretical length of 2.9 $\mathrm{cm}$, and ensiled in a large bunker silo after inoculation with 100,000 cfu/g of wet silage (H/MF inoculant, Medipharm USA, Des Moines, IA; Table 1). Corn silage was a brown midrib variety (F657, Cargill Hybrid Seeds, Minneapolis, MN) harvested at about one-half milk line, chopped to a theoretical length of $1.9 \mathrm{~cm}$, field-processed with rolling (roller clearance of 1 to 3 $\mathrm{mm}$ ), and ensiled in a large upright silo without additives (Table 1). The covariate diet was formulated from these silages, high-moisture shelled corn (rolled to a geometric mean particle size of about $2 \mathrm{~mm}$; Broderick et al., 2001), $48 \% \mathrm{CP}$ solvent-extracted soybean meal (SBM), roasted soybeans, a fat supplement (Energy Booster 100, Milk Specialties, Dundee, IL), corn starch, plus minerals and vitamins (Table 2). The 4 experimental diets were similar except that corn starch was replaced in stepwise increments of 2.5 percentage units with sucrose so that diets ranged from 7.5 to $0 \%$ added corn starch and from 0 to $7.5 \%$ added sucrose (Table $2)$. Also, roasted soybeans in the covariate diet were replaced by SBM to reduce dietary RUP to make cows more responsive to changes in microbial protein supply (Table 2). All diets were fed as TMR.

Cows were milked twice daily and individual milk yields were recorded at each milking. Milk samples were collected at 2 consecutive (p.m. and a.m.) milkings midway through wk 2 of the covariate period and midway through wk 2, 4, 6, and 8 of each experimental phase and analyzed for fat, true protein, lactose, and SNF by infrared analysis (AgSource, Verona, WI) with a Foss FT6000 (Foss North America Inc., Eden Prairie, MN) using AOAC (1990) method 972.16. For MUN determination, $5 \mathrm{~mL}$ of milk sample from both milkings was treated with $5 \mathrm{~mL}$ of $25 \%$ (wt/vol) TCA. Samples were vortexed and allowed to stand for $30 \mathrm{~min}$ at room temperature before filtering through Whatman no. 1 filter paper. Filtrates were stored at $-20^{\circ} \mathrm{C}$ until MUN analysis by an automated colorimetric assay (Broderick and Clayton, 1997) adapted to flow-injection (Lachat Quik-Chem 8000 FIA, Lachat Instruments, Milwaukee, WI). Concentrations and yields of fat, true protein, lactose, and SNF, and MUN concentration were computed as the weighted means from a.m. and p.m. milk yields on each test day. Yields of 3.5\% FCM (Sklan et al., 1992) and SCM (Tyrrell and Reid, 1965) were also computed. Efficiency of conversion of feed DM was calculated for each cow over each 2-wk interval of the experimental phase by dividing mean yield of actual milk, FCM, and SCM by mean DM intake. Similarly, efficiency of utilization of feed $\mathrm{N}$ was computed for each cow by dividing mean milk $\mathrm{N}$ output (milk true protein/6.38) by mean $\mathrm{N}$ intake, assuming no net deposit or mobilization of $\mathrm{N}$ from body tissues. Body weights were measured on 3 consecutive days at the start and end of the 8-wk experimental phase to compute BW change.

All cows were injected with bST (500 mg of Posilac, Monsanto, St. Louis, MO) on the same day at 14-d intervals throughout the trial. Cows were housed in tie 
Table 2. Composition of diets

\begin{tabular}{|c|c|c|c|c|c|}
\hline & Covariate & $\mathrm{A}$ & B & $\mathrm{C}$ & $\mathrm{D}$ \\
\hline \multicolumn{6}{|c|}{$(\%$ of $\mathrm{DM})$} \\
\hline Alfalfa silage & 41.0 & 38.8 & 38.8 & 38.8 & 38.8 \\
\hline Corn silage & 20.4 & 20.8 & 20.8 & 20.8 & 20.8 \\
\hline High-moisture shelled corn & 20.4 & 20.7 & 20.7 & 20.7 & 20.7 \\
\hline Fat supplement ${ }^{1}$ & 1.4 & 2.0 & 2.0 & 2.0 & 2.0 \\
\hline Corn starch & 6.8 & 7.6 & 5.0 & 2.5 & 0.0 \\
\hline Sucrose & 0.0 & 0.0 & 2.5 & 5.0 & 7.6 \\
\hline Sodium bicarbonate & 0.4 & 0.4 & 0.4 & 0.4 & 0.4 \\
\hline Salt & 0.3 & 0.3 & 0.3 & 0.3 & 0.3 \\
\hline Dicalcium phosphate & 0.2 & 0.2 & 0.2 & 0.2 & 0.2 \\
\hline Vitamin-mineral concentrate $^{2}$ & 0.1 & 0.1 & 0.1 & 0.1 & 0.1 \\
\hline $\mathrm{ADF}$ & 19.8 & 20.7 & 20.0 & 20.8 & 20.5 \\
\hline Acid detergent lignin & 3.6 & 4.7 & 4.1 & 4.1 & 4.2 \\
\hline Fat & 4.6 & 4.0 & 4.0 & 4.0 & 4.0 \\
\hline NDIN, $\%$ of total $\mathrm{N}$ & 3.5 & 3.0 & 3.3 & 3.3 & 2.8 \\
\hline ADIN, $\%$ of total $\mathrm{N}$ & 1.6 & 1.7 & 2.0 & 1.8 & 1.7 \\
\hline NFC & 42.3 & 42.7 & 43.7 & 42.6 & 42.8 \\
\hline $\mathrm{NSC}^{3}$ & 25.4 & 30.9 & 32.5 & 31.6 & 31.5 \\
\hline Starch $^{3}$ & 22.9 & 28.2 & 27.4 & 24.5 & 21.5 \\
\hline Total sugar ${ }^{3}$ & 2.6 & 2.7 & 5.1 & 7.1 & 10.0 \\
\hline Recovered added sugar ${ }^{3}$ & - & 0.0 & 2.4 & 4.4 & 7.3 \\
\hline
\end{tabular}

${ }^{1}$ Fat supplement ("Energy Booster 100") obtained from Milk Specialties (Dundee, IL).

${ }^{2}$ Provided (per kilogram of DM) $56 \mathrm{mg}$ of Zn, $46 \mathrm{mg}$ of Mn, $22 \mathrm{mg}$ of Fe, $12 \mathrm{mg}$ of Cu, $0.9 \mathrm{mg}$ of I, $0.4 \mathrm{mg}$ of Co, $0.3 \mathrm{mg}$ of Se, 6,440 IU of vitamin $\mathrm{A}, 2,000 \mathrm{IU}$ of vitamin $\mathrm{D}$, and $16 \mathrm{IU}$ of vitamin $\mathrm{E}$.

${ }^{3}$ Based on NSC determinations conducted by T. K. M. Webster of West Virginia University (Morgantown).

stalls and had free access to water during the trial. The TMR were offered once daily at about $1000 \mathrm{~h}$; orts were collected and recorded once daily at about $0900 \mathrm{~h}$. The feeding rate was adjusted daily to yield orts of about 5 to $10 \%$ of intake. Weekly composites of the TMR, orts, alfalfa silage, corn silage, and high-moisture corn were collected from daily samples of about $0.5 \mathrm{~kg}$ and stored at $-20^{\circ} \mathrm{C}$. Weekly samples of dry ingredients were stored at 21 to $24^{\circ} \mathrm{C}$. Proportions of each ration ingredient on an as-fed basis were adjusted weekly based on DM determined by drying weekly composites at $60^{\circ} \mathrm{C}(48 \mathrm{~h})$ for alfalfa silage, corn silage, and high-moisture shelled corn and at $105^{\circ} \mathrm{C}$ (AOAC, 1980) for roasted soybeans (for covariate period), SBM, corn starch, and sucrose; the fat supplement and mineral-vitamin supplement were assumed to have $100 \%$ DM. Intake of DM was computed based on the $60^{\circ} \mathrm{C} \mathrm{DM}$ values for TMR and orts. After drying, major dietary ingredients and TMR were ground through a 1-mm screen (Wiley mill, Arthur H. Thomas, Philadelphia, PA) and then analyzed for $\mathrm{DM}$ at $105^{\circ} \mathrm{C}$, ash and $\mathrm{OM}$ (AOAC, 1980), total $\mathrm{N}$ by combustion assay (Leco 2000, Leco Instruments
Inc., St. Joseph, MI), and sequentially for NDF and ADF using heat-stable amylase (Van Soest et al., 1991) and $\mathrm{Na}_{2} \mathrm{SO}_{3}$ (Hintz et al., 1995) during the NDF step. The TMR composites also were analyzed for total fat (method 920.39; AOAC, 1997; Dairyland Laboratories, Arcadia, WI) to compute NFC and for soluble sugars using sucrose as the standard and for starch (Hall et al., 1999; T. K. M. Webster, West Virginia Univ., Morgantown). Data on composition in Table 2 were from analysis of TMR composites. At the end of the trial, weekly composites of alfalfa silage and corn silage were thawed and water extracts were prepared, deproteinized, and then analyzed for NPN (Muck, 1987) using a combustion $\mathrm{N}$ assay (Mitsubishi TN-05 Nitrogen Analyzer, Mitsubishi Chemical Corp., Tokyo, Japan).

At the end of wh 4 and 8 of each experimental phase, 2 spot urine samples were collected from all cows at about 6 and $18 \mathrm{~h}$ after feeding. Fresh urine was acidified by diluting $15 \mathrm{~mL}$ of urine with $60 \mathrm{~mL}$ of 0.072 $N \mathrm{H}_{2} \mathrm{SO}_{4}$ and storing at $-20^{\circ} \mathrm{C}$ until analyzed. At the end of the trial, all urine samples were thawed at room temperature and filtered through Whatman no. 1 filter 
paper. Filtrates were analyzed for creatinine using a picric acid assay (Oser, 1965) adapted to the flowinjection analyzer (Lachat Quick-Chem, Lachat Instruments), for total N (Mitsubishi Nitrogen Analyzer), for allantoin using the method of Vogels and van der Grift (1970) adapted to a 96-well plate reader, for uric acid using a commercial kit (No. 683-100P, Sigma Chem. Co., St. Louis, MO), and for urea with the colorimetric method used for MUN. Daily urine volume and excretion of urea $\mathrm{N}$, total $\mathrm{N}$, and purine derivatives (PD; allantoin plus uric acid) were estimated from mean urinary concentrations assuming a creatinine excretion rate of $29 \mathrm{mg} / \mathrm{kg}$ of BW (Valadares et al., 1999).

\section{Ruminal Metabolism Trial}

At the same time as the lactation trial, an additional 4 lactating Holstein cows fitted with permanent ruminal cannulae and with mean (SD) parity of $3.0(0.8), 662$ (69) $\mathrm{kg}$ of BW, 185 (88) DIM, and 39 (5) kg of milk/d were assigned to a balanced $4 \times 4$ Latin square trial with 4 -wk periods (total 16 wk). These cows were fed the same 4 experimental diets over the same time period and were housed and managed as described in the lactation trial. Omasal sampling was performed during the last week of each period using the techniques developed by Huhtanen et al. (1997) and Ahvenjarvi et al. (2000), as modified by Reynal and Broderick (2003), to quantify ruminal digesta flow. Indigestible NDF (Huhtanen et al., 1994), $\mathrm{YbCl}_{3}$ (Siddons et al., 1985), and Co-EDTA (Uden et al., 1980), which are mainly associated with, respectively, large particle, small particle, and fluid phases of digesta, were used as flow markers at the omasal canal. Cobalt-EDTA and $\mathrm{YbCl}_{3}$ were dissolved in distilled water and continuously infused into the rumen at rates of $2.6 \mathrm{~g}$ of $\mathrm{Co}$ and $2.2 \mathrm{~g}$ of $\mathrm{Yb}$, in $3.12 \mathrm{~L} / \mathrm{d}$ of solution. Markers were continuously infused for $158 \mathrm{~h}$ from d 20 at $0900 \mathrm{~h}$ to d 26 at $2300 \mathrm{~h}$ using a syringe pump (model 33, Harvard Apparatus Inc., Holliston, MA). Spot samples of $300 \mathrm{~mL}$ of digesta were collected over $3 \mathrm{~d}$ from the omasal canal 4 times/d at 2-h intervals at 0000, 0200, 0400, $0600 \mathrm{~h} \mathrm{(d} \mathrm{24),}$ 0800, 1000, 1200, $1400 \mathrm{~h}$ (d 25), and 1600, 1800, 2000, and $2200 \mathrm{~h}$ (d 26), such that sampling represented the 24-h feeding cycle. Each spot sample was divided into subsamples of 100 and $200 \mathrm{~mL} ; 1 \mathrm{~mL}$ of $40 \%$ (wt/vol) formaldehyde was added to the 100-mL subsample. Subsamples were pooled as they were collected over all sampling times to yield 1.2- and 2.4-L composites from each cow in each period. Pooled subsamples were stored at $-20^{\circ} \mathrm{C}$ until processed.

The 2.4-L pooled omasal composites were thawed at room temperature, separated into the large particle, small particle, and fluid phases, freeze-dried, and ana- lyzed for $\mathrm{Co}, \mathrm{Yb}$, and indigestible NDF. Then, DM from freeze-dried was phase mixed in the correct proportions to reconstitute the omasal true digesta (OTD) flowing out of the rumen based on the triple-marker method of France and Siddons (1986), as detailed by Reynal and Broderick (2003). The OTD samples were analyzed for DM, ash, NDF, ADF, and total $\mathrm{N}$ as described for feeds, as well as for NAN and individual purines (Reynal and Broderick, 2009). The 1.2-L pooled omasal composites were thawed at room temperature and centrifuged $\left(176 \times g, 4^{\circ} \mathrm{C}, 5 \mathrm{~min}\right)$; supernatants were decanted and recentrifuged $\left(11,300 \times g, 4^{\circ} \mathrm{C}, 30 \mathrm{~min}\right)$. This second supernatant was decanted and discarded and the pellet resuspended in $100 \mathrm{~mL}$ of McDougall's buffer and recentrifuged $\left(11,300 \times g, 4^{\circ} \mathrm{C}, 30 \mathrm{~min}\right)$. The resulting bacterial pellets were stored at $-20^{\circ} \mathrm{C}$ until freeze-dried, ground with a mortar and pestle, and then analyzed for ash as described for feeds and for NAN and individual purines (Reynal and Broderick, 2009). Omasal flows and apparent ruminal digestion of DM, $\mathrm{OM}, \mathrm{NDF}, \mathrm{ADF}$ and $\mathrm{N}$; omasal flows of microbial DM, $\mathrm{OM}$, and NAN; true ruminal digestion of $\mathrm{DM}, \mathrm{OM}$, and $\mathrm{N}$; and microbial efficiency ( $\mathrm{g}$ of microbial NAN $/ \mathrm{kg}$ of OM truly digested in the rumen) were computed from analytical data using the equations detailed earlier (Reynal and Broderick, 2003).

On d 27 of each period, about 100 to $200 \mathrm{~mL}$ of digesta was collected from 3 locations in the ventral rumen at 0 (just before feeding), $1,2,4,6,8$, and $12 \mathrm{~h}$ after the feeding, and strained through 2 layers of cheesecloth; $\mathrm{pH}$ was measured immediately. Two $10-\mathrm{mL}$ samples of ruminal fluid were then preserved in scintillation vials by addition of $0.2 \mathrm{~mL}$ of $50 \% \mathrm{H}_{2} \mathrm{SO}_{4}$ and stored at $-20^{\circ} \mathrm{C}$. Just before analysis, samples were thawed and centrifuged $\left(15,300 \times g\right.$ for $20 \mathrm{~min}$ at $\left.4^{\circ} \mathrm{C}\right)$ and flow-injection analyses (dual-channel Quik-Chem 8000 FIA, Lachat Instruments) were applied to supernatants to determine ammonia, using a phenol-hypochlorite method (Lachat method 18-107-06-1-A), and total AA using a fluorimetric procedure based on reaction with o-phthalaldehyde (Roth, 1971). Leucine was the standard in the o-phthalaldehyde assay and total AA are reported in leucine equivalents. Samples also were thawed and centrifuged $\left(28,000 \times g\right.$ for $30 \mathrm{~min}$ at $\left.4^{\circ} \mathrm{C}\right)$ for determination of individual and total ruminal VFA using a modification of the GLC method for free fatty acids described in Supelco Bulletin 855B (Supelco Inc., Supelco Park, Bellefonte, PA) with flame-ionization detection. Standards or supernatants $(0.5$ or $1 \mu \mathrm{L})$ were injected onto a ZB-FFAP capillary column $(30 \mathrm{~m} \times 0.53$ $\mathrm{mm} \times 1.0 \mu \mathrm{m}$; no. 7HK-G009-22, Phenomenex Inc., Torrance, CA) with helium carrier gas at $100 \mathrm{kPa}$ and a flow rate of $20 \mathrm{~mL} / \mathrm{min}$. Column oven temperature was $100^{\circ} \mathrm{C}$ at injection; after $2 \mathrm{~min}$., temperature was 
increased to $130^{\circ} \mathrm{C}$ at $10^{\circ} \mathrm{C} / \mathrm{min}$. Injector and detector temperatures were 230 and $250^{\circ} \mathrm{C}$. The method did not resolve isovalerate and 2-methylbutyrate. Individual VFA are reported in concentration units rather than as molar proportions.

\section{Statistical Analysis}

Statistical analysis of most data from the lactation trial was conducted using the mixed procedures of SAS (SAS Institute, 1999) with a repeated measures model using an $\mathrm{SP}(\mathrm{POW})$ structure that included the covariate mean for each trait for each cow, phase, block, diet (sucrose level), and wk $(2,4,6$, and 8), plus the interactions phase $\times$ diet, phase $\times$ week, diet $\times$ week, and the 3 -way interaction phase $\times$ diet $\times$ week. The same approach was used for BW change, MUN, and excretion traits except the model did not contain the covariate. All variables were considered fixed, except cow, whole-plot error, and subplot error, which were considered random. Interaction terms were removed from the model when $P \geq 0.25$. Least squares mean estimates for each level of sucrose are reported. Orthogonal contrasts were used to test for linear and quadratic effects of level of sucrose addition to the diet. Significance was declared at $P \leq 0.05$ and separation of least squares means was conducted at $\alpha=0.05$ using pdiff in the lsmeans statement.

Data from ruminal and omasal sampling were analyzed as a $4 \times 4$ Latin square using the mixed procedures of SAS (SAS Institute, 1999). Model sums of squares for traits measured at different times after feeding were separated into overall mean, cow, period, diet, wholeplot error, hours postfeeding (repeated measures), hours postfeeding $\times$ diet interaction, and subplot error. Repeated measures analyses were performed using the SP(POW) structure of SAS. The hours postfeeding and repeated measures portion of the model were deleted for the analysis of omasal sampling data. All variables were considered fixed, except cow, whole-plot error, and subplot error, which were considered random. The interaction term square $\times$ diet was removed from the model when $P \geq 0.25$. Orthogonal contrasts were used to test for linear and quadratic effects of level of sucrose addition to the diet. Significance was declared at $P \leq 0.05$ and separation of least squares means was conducted at $\alpha=0.05$ using pdiff in the lsmeans statement.

\section{RESULTS AND DISCUSSION}

The alfalfa and corn silages fed in this study both contained 43 to $44 \% \mathrm{NDF}$ and had expected levels of ammonia-N, total AA-N, and ADIN, indicating that they resulted from typical fermentations in the silo
(Table 1) and were of usual composition (NRC, 2001). Both the alfalfa silage (Broderick et al., 2001) and corn silage (McDonald et al., 1991) contained the normal, high proportions of NPN, and forage NPN accounted for a mean $42 \%$ of total dietary N. Large amounts of NPN depress utilization of forage CP (Nagel and Broderick, 1992). These levels of CP and NPN indicated that possible responses in microbial growth from supplemental sucrose would not have been restricted by RDP supply on this trial. Targets for corn starch and sucrose addition were very nearly met despite variation in ingredient DM content over the course of the trial (Table 2). Nonstructural carbohydrate analysis of TMR composites indicated that stepwise replacement of corn starch (in increments of 2.5 percentage units) with sucrose increased total sugar from 2.7 to $10.0 \%$ of dietary DM. Using these data to quantify added sugar, 2.4, 4.4 , and $7.3 \%$ of dietary DM was recovered versus the targets of 2.5, 5.0, and 7.5\% added sucrose (Table 2). These results indicate that the 4 diets conformed to our experimental plan of linear incremental replacement of starch with sugar.

Although no quadratic contrasts were significant $(P$ $\geq 0.26$ ), several linear responses to replacing dietary starch with sucrose were detected for production traits (Table 3). There was a linear increase $(P=0.02)$ in DM intake with increasing dietary sugar (Table 3 ), an effect we observed previously when making incremental additions of both dried and liquid molasses at the expense of high-moisture corn (Broderick and Radloff, 2004). Sutton et al. (2001) reported elevated feed intake by dairy cattle when increasing dietary sugar levels. This effect may be mediated partly through improved palatability. Harvesting forages in late afternoon, just after maximal photosynthetic activity, increased total sugar content (Owens et al., 1999). Dry matter intake was elevated in goats, sheep, and cattle when they were fed fescue hay (Fisher et al., 1999) or alfalfa hay (Fisher et al., 2002) harvested late in the day versus hay harvested in early morning.

Milk yield was not altered, but there were linear increases $(P \leq 0.05)$ in milk fat content and secretion with elevated dietary sucrose (Table 3 ). Similar effects have been reported by others when feeding molasses to lactating cows (Wing et al., 1988; Murphy, 1999). However, quadratic responses to increasing dietary sugar, added incrementally as molasses, have also been observed (Broderick and Radloff, 2004). Both acetate and butyrate are important precursors for de novo fatty acid synthesis for milk fat formation (Bauman and Griinari, 2001). Increased fat secretion due to sugar feeding has been attributed to elevated butyrate production in the rumen (Khalili and Huhtanen, 1991). However, increasing dietary sucrose did not alter ruminal concentrations 
Table 3. Effect of replacing dietary corn starch with sucrose on production and urinary excretion

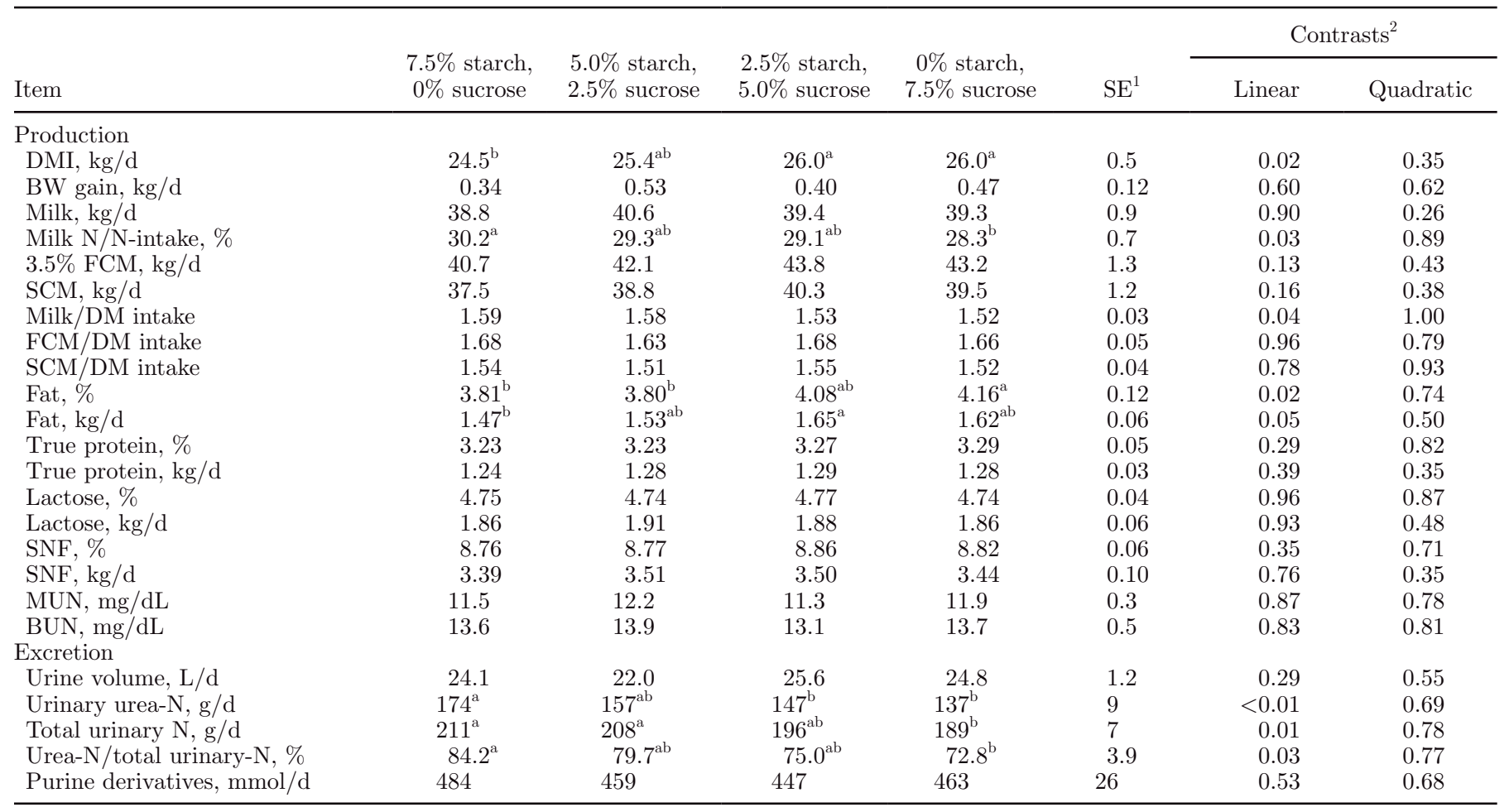

${ }^{a, b}$ Least squares means within the same row without a common superscript differ $(P<0.05)$.

${ }^{1}$ Standard error of the least squares means.

${ }^{2}$ Probability of linear and quadratic orthogonal contrasts for dietary sucrose concentration.

of either total VFA or butyrate; moreover, both acetate and acetate:propionate ratio declined $(P \leq 0.04)$ in the present trial (Table 4$)$. Valerate, for which there was a quadratic response $(P=0.02)$ to sucrose (Table 4$)$, can be formed partly from condensation and reduction of acetate and propionate (Prins, 1977); this could have been the fate of a small proportion of these 2 VFA. Concentrations of VFA in the rumen represent a balance between production and disappearance, and important differences in VFA production may not be apparent from concentrations alone (Leng, 1970; Dijkstra et al., 1993). Vallimont et al. (2004), when feeding the same 4 TMR from the present study to continuous culture systems charged with ruminal inoculum, observed a linear increase in butyrate and decline in glucogenic:lipogenic VFA ratio in fermenter effluent as sucrose replaced corn starch. Because VFA absorption would not confound the relationship between concentration and production rate, increased concentrations in continuous culture might indicate that butyrate production was also increased in the rumen in vivo. Mean ruminal $\mathrm{pH}$ was normal over the $12 \mathrm{~h}$ after feeding for a regimen in which animals were fed once daily and was unaffected by diet (Table 4), suggesting that no ill effects ensued from feeding diets with $43 \%$ NFC and 31 to $33 \%$ NSC.
Linear decreases $(P<0.04)$ were observed in apparent DM efficiency (milk yield/DM intake) and $\mathrm{N}$ efficiency (milk N/N-intake) with increasing dietary sugar (Table 3). This occurred because the response in DM intake was not accompanied by a change in actual milk. However, no effect was detected $(P \geq 0.78)$ when efficiency was expressed as FCM/DM intake or SCM/DM intake. The numerical increases in secretion of FCM and SCM, although not significant $(P \geq 0.13)$, were large enough to dilute the effect of elevated DM intake when computing feed efficiencies. This result indicated that energy utilization was not impaired at the greater DM intakes occurring when sucrose replaced dietary starch.

Depressed N efficiency $(P=0.04)$ also occurred because greater $\mathrm{N}$ intake was not reflected in a response $(P=0.39)$ in true protein yield (Table 3$)$. Although MUN was unchanged, increased dietary sucrose was accompanied by affects usually associated with improved $\mathrm{N}$ utilization. Urinary urea-N $(P<0.01)$, total $\mathrm{N}(P$ $=0.01)$, and urea- $\mathrm{N}$ as a proportion of total urinary $\mathrm{N}$ $(P=0.03)$ all declined with elevated dietary sucrose. Earlier, we observed quadratic effects on milk protein yield and ruminal ammonia with supplementation of liquid molasses in cows fed diets with $32 \%$ alfalfa silage 
Table 4. Effect of replacing dietary corn starch with sucrose on $\mathrm{pH}$ and concentration of metabolites in the rumen

\begin{tabular}{|c|c|c|c|c|c|c|c|}
\hline \multirow[b]{2}{*}{ Item } & \multirow[b]{2}{*}{$\begin{array}{l}7.5 \% \text { starch, } \\
0 \% \text { sucrose }\end{array}$} & \multirow[b]{2}{*}{$\begin{array}{l}5.0 \% \text { starch, } \\
2.5 \% \text { sucrose }\end{array}$} & \multirow[b]{2}{*}{$\begin{array}{l}2.5 \% \text { starch, } \\
5.0 \% \text { sucrose }\end{array}$} & \multirow[b]{2}{*}{$\begin{array}{l}0 \% \text { starch, } \\
7.5 \% \text { sucrose }\end{array}$} & \multirow[b]{2}{*}{$\mathrm{SE}^{1}$} & \multicolumn{2}{|c|}{ Contrasts $^{2}$} \\
\hline & & & & & & Linear & Quadratic \\
\hline $\mathrm{pH}$ & 6.19 & 6.16 & 6.18 & 6.21 & 0.11 & 0.74 & 0.65 \\
\hline Total AA, mM & 4.32 & 3.45 & 3.31 & 3.61 & 0.55 & 0.26 & 0.20 \\
\hline Total VFA, mM & 114.0 & 117.3 & 114.1 & 111.3 & 5.0 & 0.31 & 0.22 \\
\hline Acetate $(\mathrm{A}), \mathrm{m} M$ & $73.5^{\mathrm{a}}$ & $74.5^{\mathrm{a}}$ & $72.0^{\mathrm{ab}}$ & $69.4^{\mathrm{b}}$ & 3.1 & 0.04 & 0.24 \\
\hline Isobutyrate, $\mathrm{m} M$ & $1.24^{\mathrm{b}}$ & $1.33^{\mathrm{a}}$ & $1.24^{\mathrm{b}}$ & $1.15^{\mathrm{c}}$ & 0.06 & 0.01 & $<0.01$ \\
\hline $\begin{array}{l}\text { Isovalerate } \\
\quad+2 \text {-methylbutyrate, } \mathrm{m} M\end{array}$ & $1.81^{\mathrm{b}}$ & $2.00^{\mathrm{a}}$ & $1.78^{\mathrm{b}}$ & $1.57^{\mathrm{c}}$ & 0.24 & $<0.01$ & 0.01 \\
\hline $\mathrm{BCVFA},{ }^{3} \mathrm{~m} M$ & $3.04^{\mathrm{b}}$ & $3.33^{\mathrm{a}}$ & $3.01^{\mathrm{b}}$ & $2.72^{\mathrm{c}}$ & 0.30 & $<0.01$ & $<0.01$ \\
\hline Valerate, $\mathrm{m} M$ & $1.76^{\mathrm{b}}$ & $1.99^{\mathrm{a}}$ & $1.91^{\mathrm{ab}}$ & $1.82^{\mathrm{ab}}$ & 0.12 & 0.78 & 0.02 \\
\hline
\end{tabular}

${ }^{\mathrm{a}-\mathrm{c}}$ Least squares means within the same row without a common superscript differ $(P<0.05)$.

${ }^{1}$ Standard error of the least squares means.

${ }^{2}$ Probability of linear and quadratic orthogonal contrasts for dietary sucrose concentration.

${ }^{3}$ Branched-chain VFA computed as the sum of isobutyrate and isovalerate plus 2-methylbutyrate.

and $15.6 \% \mathrm{CP}$; milk protein secretion increased and ruminal ammonia declined with consumption of 0.7 , but not 1.3 and $2.0, \mathrm{~kg} / \mathrm{d}$ of added total sugar (Broderick and Radloff, 2004). However, a second trial found no significant effect on protein secretion when adding dried molasses to diets with $40 \%$ alfalfa silage and $17.9 \% \mathrm{CP}$ (Broderick and Radloff, 2004). Intake of added total sugar, assayed by the same method as earlier, was 0.6, 1.1 , and $1.9 \mathrm{~kg} / \mathrm{d}$ in the current study.

Although not different among diets, typical magnitudes of digesta flow at the omasal canal and ruminal digestibility were measured in this study (Table 5). Mean microbial OM flow (determined with total purines as the microbial marker; Reynal and Broderick, 2009) was $5.1 \mathrm{~kg} / \mathrm{d}$; mean apparent and true (i.e., corrected for microbial $\mathrm{OM}$ flow at the omasum) OM digestibility in the rumen was 40 and $62 \%$. Reynal et al. (2003) observed $4.9 \mathrm{~kg} / \mathrm{d}$ of microbial $\mathrm{OM}$ flow (estimated using a similar total purine assay) and apparent and true OM digestibility of 42 and $67 \%$ in dairy cows fed diets based on corn silage and high-moisture corn and supplemented with 5 different $\mathrm{CP}$ sources. Using ${ }^{15} \mathrm{~N}$ as a microbial marker, Brito et al. (2006) found $5.4 \mathrm{~kg} / \mathrm{d}$ of microbial OM flow and apparent and true OM digestibility of 42 and $64 \%$ on diets containing a range of contents of alfalfa and corn silages plus high-moisture corn. Brito et al. (2007) observed $4.6 \mathrm{~kg} / \mathrm{d}$ of microbial OM flow and apparent and true OM digestibility of 45 and $65 \%$ in cows fed diets containing alfalfa and corn silages, high-moisture corn, and 1 of $4 \mathrm{CP}$ sources. The mean ruminal digestibilities of 52 and $58 \%$ for NDF and ADF were relatively high, confirming that there was active fermentation in the rumen. Greater digestibility of ADF than NDF implies that hemicellulose was less digestible than ADF, which is composed of cellulose plus lignin. We have observed greater apparent digestibility of ADF than NDF in previous trials in which two-thirds (Broderick and Radloff, 2004) or all (Broderick et al., 2001) dietary forage came from alfalfa silage, but not when all dietary forage came from red clover silage (Broderick et al., 2001). Weiss et al. (1989) reported apparent digestibilities of $49,55,28$, and $64 \%$ for, respectively, NDF, ADF, hemicellulose, and cellulose on a $30 \%$ NDF diet composed principally of alfalfa silage and corn grain in which the alfalfa provided $89 \%$ of the dietary NDF. We observed fiber digestibilities of 27 to $35 \%$ (Brito et al., 2006) and 28 to $36 \%$ (Brito et al., 2007) in earlier work using similar methodology but in diets containing more mature alfalfa silage and at $\mathrm{NDF}$ and $\mathrm{ADF}$ intakes that were 1.0 to $1.5 \mathrm{~kg} / \mathrm{d}$ greater. A quadratic effect of diet on apparent ruminal NDF digestibility was also detected in the current trial, with digestion maximizing at about $5 \%$ sucrose before declining. Vallimont et al. (2004) found a similar quadratic effect and a mean NDF digestibility of $61 \%$ when feeding these same 4 diets to continuous culture fermenters.

As detected in previous work (Reynal et al., 2003; Brito et al., 2006, 2007), apparent $\mathrm{N}$ digestion in the rumen was slightly negative on all diets; moreover, this response was linear $(P=0.02)$ whereby the effect became less negative as dietary sucrose increased (Table 5). Trapping of urea- $\mathrm{N}$ recycled to rumen is commonly observed such that apparent $\mathrm{N}$ digestion often appears to be negative. The effect of diet on apparent $\mathrm{N}$ digestibility disappeared when $\mathrm{N}$ digestibility was corrected for microbial NAN flow at the omasal canal. It was anticipated that sugar supplementation would be benefi- 
Table 5. Effect of replacing dietary corn starch with sucrose on composition of isolated ruminal bacteria, nutrient flow from and digestion in the rumen, and microbial protein yield

\begin{tabular}{|c|c|c|c|c|c|c|c|}
\hline Item & $\begin{array}{l}7.5 \% \text { starch, } \\
0 \% \text { sucrose }\end{array}$ & $\begin{array}{l}5.0 \% \text { starch, } \\
2.5 \% \text { sucrose }\end{array}$ & $\begin{array}{l}2.5 \% \text { starch, } \\
5.0 \% \text { sucrose }\end{array}$ & $\begin{array}{c}0 \% \text { starch, } \\
7.5 \% \text { sucrose }\end{array}$ & $\mathrm{SE}^{1}$ & \multicolumn{2}{|c|}{ Contrasts $^{2}$} \\
\hline Bacterial NAN, $\%$ of DM & 7.16 & 7.32 & 7.48 & 7.44 & 0.13 & 0.12 & 0.45 \\
\hline Bacterial purines, $\mu \mathrm{mol} / \mathrm{g}$ of $\mathrm{DM}$ & $110^{\mathrm{b}}$ & $116^{\mathrm{ab}}$ & $118^{\mathrm{ab}}$ & $121^{\mathrm{a}}$ & 5 & 0.02 & 0.61 \\
\hline \multicolumn{8}{|l|}{ DM } \\
\hline Intake, $\mathrm{kg} / \mathrm{d}$ & 24.7 & 25.4 & 26.3 & 25.9 & 1.0 & 0.18 & 0.46 \\
\hline Microbial DM, g/d & 6.51 & 6.14 & 6.11 & 5.83 & 0.46 & 0.22 & 0.91 \\
\hline \multicolumn{8}{|l|}{ OM } \\
\hline Intake, $\mathrm{kg} / \mathrm{d}$ & 22.9 & 23.6 & 24.3 & 24.1 & 0.9 & 0.18 & 0.48 \\
\hline Omasal flow, kg/d & 14.4 & 14.1 & 14.2 & 14.3 & 0.9 & 0.99 & 0.78 \\
\hline Apparent digestion, $\mathrm{kg} / \mathrm{d}$ & 8.55 & 9.54 & 10.1 & 9.74 & 0.49 & 0.11 & 0.21 \\
\hline Apparent digestion, $\%$ & 37.1 & 40.8 & 41.7 & 40.5 & 2.2 & 0.30 & 0.31 \\
\hline Microbial OM, g/d & 5.50 & 4.91 & 5.14 & 4.85 & 0.41 & 0.12 & 0.50 \\
\hline Apparent digestion, $\mathrm{kg} / \mathrm{d}$ & 3.71 & 3.89 & 4.44 & 3.77 & 0.27 & 0.46 & 0.09 \\
\hline Apparent digestion, \% & 49.8 & 52.6 & 57.5 & 49.3 & 3.4 & 0.73 & 0.04 \\
\hline \multicolumn{8}{|l|}{ ADF } \\
\hline Intake, $\mathrm{kg} / \mathrm{d}$ & 5.10 & 5.07 & 5.44 & 5.32 & 0.20 & 0.11 & 0.71 \\
\hline Omasal flow, $\mathrm{kg} / \mathrm{d}$ & 2.28 & 2.18 & 1.91 & 2.43 & 0.20 & 0.84 & 0.15 \\
\hline Apparent digestion, $\mathrm{kg} / \mathrm{d}$ & 2.81 & 2.89 & 3.53 & 2.89 & 0.23 & 0.42 & 0.15 \\
\hline Apparent digestion, $\%$ & 54.7 & 57.4 & 65.1 & 54.2 & 3.9 & 0.73 & 0.13 \\
\hline \multicolumn{8}{|l|}{ Nitrogen } \\
\hline $\mathrm{N}$ intake, $\mathrm{g} / \mathrm{d}$ & 655 & 676 & 703 & 702 & 24 & 0.05 & 0.49 \\
\hline Omasal N flow, $\mathrm{g} / \mathrm{d}$ & 758 & 733 & 778 & 734 & 30 & 0.81 & 0.69 \\
\hline Apparent digestion, $\mathrm{g} / \mathrm{d}$ & $-102^{\mathrm{a}}$ & $-57^{\mathrm{ab}}$ & $-75^{\mathrm{ab}}$ & $-32^{\mathrm{b}}$ & 16 & 0.02 & 0.93 \\
\hline Apparent digestion, $\%$ & $-15.9^{\mathrm{a}}$ & $-7.7^{\mathrm{b}}$ & $-10.6^{\mathrm{ab}}$ & $-4.8^{\mathrm{b}}$ & 2.5 & 0.02 & 0.64 \\
\hline Microbial NAN, g/d & 466 & 445 & 452 & 433 & 32 & 0.45 & 0.98 \\
\hline Microbial efficiency $^{3}$ & 33.4 & 30.8 & 29.6 & 29.7 & 2.1 & 0.24 & 0.54 \\
\hline
\end{tabular}

cial through stimulation of microbial protein formation from dietary RDP. Ruminal concentrations of ammonia and individual and total branched-chain VFA (precursors of branched-chain AA in some ruminal organisms; Allison, 1970) declined linearly $(P \leq 0.05)$ in response to increasing dietary sucrose (Table 4 ). Vallimont et al. (2004), when feeding these diets to continuous culture fermenters, observed a linear decline in isobutyrate, but not isovalerate or ammonia. However, no effects of increasing dietary sucrose on microbial protein formation in the rumen were detected; mean bacterial NAN flow was $449 \mathrm{~g} / \mathrm{d}$ across diets in this study (Table 5). Moreover, urinary excretion of purine derivatives (Table 3 ), which are indirectly related to microbial flow from the rumen (Chen et al., 1990; Vagnoni et al., 1997), also did not alter. Microbial efficiency averaged about 31 $\mathrm{g}$ of $\mathrm{NAN} / \mathrm{kg}$ of $\mathrm{OM}$ truly fermented in the rumen. Mean efficiencies of 32 (Reynal et al., 2003), 30 (Brito et al., 2006), and 29 (Brito et al., 2007) g of NAN/kg of $\mathrm{OM}$ truly fermented in the rumen were observed in some of our earlier work. A linear effect was detected for bacterial purine concentration, which increased along with dietary sucrose. Because NAN content was unchanged $(P=0.93)$, this was not due to an effect on bacterial carbohydrate stores. Reduced mean cell size, whereby there would be greater purine per unit cell protoplasm (Obispo and Dehority, 1999), might account for the increased purine content. The quadratic effects $(P \leq 0.02$; Table 4$)$ observed for individual and total branched-chain VFA are difficult to explain. This 
pattern may derive partly from a biological interaction of increasing sucrose content of the diet and greater RDP entering the rumen due to elevated feed intake.

Literature reports are contradictory on whether replacing dietary starch with sugars, specifically sucrose, will increase microbial protein flow from the rumen. Ruminal infusions of sucrose (Kim et al., 1999a) and maltodextrin (Kim et al., 1999b) in dairy cattle fed grass silage diets stimulated microbial protein synthesis in the rumen. Kim et al. (2000) also showed a positive effect of sucrose infusion into the rumen. However, Hall and Herejk (2001) observed greater yield of microbial protein from starch than sucrose addition to ruminal in vitro incubations. Sannes et al. (2002) reported that sucrose supplementation changed total PD excretion, but not microbial protein synthesis, which was computed from $\mathrm{PD}$ excretion plus the purine: $\mathrm{N}$ ratio of isolated ruminal bacteria, and was actually reduced with sucrose feeding. Because large hexose polymers such as starch have lost the weight of 1 molecule of water of hydration per sugar unit, they are more energy dense than di-hexoses; thus, sucrose contains only $95 \%$ as much usable energy per unit weight as starch. This dilution of dietary energy may help explain the lack of a production effect, despite positive changes in ruminal microbial growth, when sucrose replaced starch in the diet.

\section{CONCLUSIONS}

Feeding sugar has been reported to improve RDP utilization in dairy cows. Stepwise replacement of corn starch with sucrose in a diet formulated from alfalfa and corn silages, high-moisture corn, and solvent-extracted SBM, and containing $16.7 \% \mathrm{CP}$ and $30 \% \mathrm{NDF}$, gave linear increases in DM intake and milk fat content and yield, as well as linear decreases in ruminal concentration of ammonia and branched-chain VFA, urinary excretion of urea- $\mathrm{N}$ and total $\mathrm{N}$, and urea-N as a proportion of total urinary N. Despite these changes, there were linear decreases in both milk/DM intake and milk $\mathrm{N} / \mathrm{N}$-intake when sucrose replaced dietary starch. However, expression of feed efficiency as FCM/DM intake or SCM/DM intake was not influenced by diet, suggesting that energy efficiency was not impaired. Increased fat secretion when sucrose replaced dietary starch was apparently mediated via increased energy intake. The positive effects on factors associated with improved $\mathrm{N}$ efficiency that were observed when sucrose was fed in this trial were not associated with improved milk protein secretion.

\section{ACKNOWLEDGMENTS}

The authors thank Rick Walgenbach and the farm crew for harvesting and storing the feedstuffs used in these trials; Len Strozinski and the barn crew for feeding and animal care at the US Dairy Forage Center Research Farm (Prairie du Sac, WI); Wendy Radloff and Mary Becker for assisting with sampling and laboratory analyses; Tammy K. Miller Webster for starch and total sugar analyses on TMR; and Peter Crump for assisting with statistical analyses. Partial financial support for this research from Conti-Group Inc. is also gratefully acknowledged.

\section{REFERENCES}

Ahvenjarvi, S., A. Vanhatalo, P. Huhtanen, and T. Varvikko. 2000. Determination of reticulo-rumen and whole-stomach digestion in lactating cows by omasal canal or duodenal sampling. Br. J. Nutr. 83:67-77.

Allison, M. J. 1970. Nitrogen metabolism of ruminal micro-organisms. Pages 456-463 in Physiology of Digestion and Metabolism in the Ruminant. A. T. Phillipson, ed. Oriel Press, Newcastle upon Tyne, UK.

Association of Official Analytical Chemists. 1980. Official Methods of Analysis. 13th ed. AOAC, Washington, DC.

Association of Official Analytical Chemists. 1990. Official Methods of Analysis. 15th ed. Association of Official Analytical Chemists, Arlington, VA.

Association of Official Analytical Chemists. 1997. Official Methods of Analysis. 16th ed. AOAC, Washington, DC.

Bauman, D. E., and J. M. Griinari. 2001. Regulation and nutritional manipulation of milk fat: Low-fat milk syndrome. Livest. Prod. Sci. 70:15-29.

Brito, A. F., G. A. Broderick, and S. M. Reynal. 2006. Effect of varying dietary ratios of alfalfa silage to corn silage on omasal flow and microbial protein synthesis in dairy cows. J. Dairy Sci. 89:3939-3953.

Brito, A. F., G. A. Broderick, and S. M. Reynal. 2007. Effects of different protein supplements on omasal nutrient flow and microbial protein synthesis in lactating dairy cows. J. Dairy Sci. 90:1828-1841.

Broderick, G. A., and M. K. Clayton. 1997. A statistical evaluation of animal and nutritional factors influencing concentrations of milk urea nitrogen. J. Dairy Sci. 80:2964-2971.

Broderick, G. A., and W. J. Radloff. 2004. Effect of molasses supplementation on the production of lactating dairy cows fed diets based on alfalfa and corn silage. J. Dairy Sci. 87:2997-3009.

Broderick, G. A., R. P. Walgenbach, and S. Maignan. 2001. Production of lactating dairy cows fed alfalfa or red clover silage at equal dry matter or crude protein contents in the diet. J. Dairy Sci. 84:1728-1737.

Chamberlain, D. G., S. Robertson, and J. J. Choung. 1993. Sugars versus starch as supplements to grass silage: Effects of ruminal fermentation and the supply of microbial protein to the small intestine, estimated from the urinary excretion of purine derivatives, in sheep. J. Sci. Food Agric. 63:189-194.

Chen, X. B., F. D. Hovell, E. R. Ørskov, and D. S. Brown. 1990. Excretion of purine derivatives by ruminants: Effect of exogenous nucleic acid supply on purine derivative excretion by sheep. $\mathrm{Br}$. J. Nutr. 63:131-142.

Dijkstra, J., H. Boer, J. Van-Bruchem, M. Bruining, and S. Tamminga. 1993. Absorption of volatile fatty acids from the rumen of lactating dairy cows as influenced by volatile fatty acid concentration, $\mathrm{pH}$ and rumen liquid volume. Br. J. Nutr. 69:385-396.

Fisher, D. S., H. F. Mayland, and J. C. Burns. 1999. Variation in ruminants' preference for tall fescue hays cut either at sundown or at sunup. J. Anim. Sci. 77:762-768.

Fisher, D. S., H. F. Mayland, and J. C. Burns. 2002. Variation in ruminant preference for alfalfa hays cut at sunup and sundown. Crop Sci. 42:231-237. 
France, J., and R. C. Siddons. 1986. Determination of digesta flow by continuous marker infusion. J. Theor. Biol. 121:105-119.

Hall, M. B., and C. Herejk. 2001. Differences in yields of microbial crude protein from in vitro fermentation of carbohydrates. J. Dairy Sci. 84:2486-2493.

Hall, M. B., W. H. Hoover, J. P. Jennings, and T. K. M. Webster. 1999. A method for partitioning neutral detergent-soluble carbohydrates. J. Sci. Food Agric. 79:2079-2086.

Hintz, R. W., D. R. Mertens, and K. A. Albrecht. 1995. Effects of sodium sulfite on recovery and composition of detergent fiber and lignin. J. AOAC 78:16-22.

Huhtanen, P., P. G. Brotz, and L. D. Satter. 1997. Omasal sampling technique for assessing fermentative digestion in the forestomach of dairy cows. J. Anim. Sci. 75:1380-1392.

Huhtanen, P., K. Kaustell, and S. Jaakkola. 1994. The use of internal markers to predict total digestibility and duodenal flow of nutrients in cattle given six different diets. Anim. Feed Sci. Technol. 48:211-227.

Khalili, H., and P. Huhtanen. 1991. Sucrose supplements in cattle given grass silage-based diet: 1 . Digestion of organic matter and nitrogen. Anim. Feed Sci. Technol. 33:247-262.

Kim, K. H., J. J. Choung, and D. G. Chamberlain. 1999b. Effects of varying the degree of synchrony of energy and nitrogen release in the rumen on the synthesis of microbial protein in lactating dairy cows consuming a diet of grass silage and a cereal-based concentrate. J. Sci. Food Agric. 79:1441-1447.

Kim, K. H., S. S. Lee, B. T. Jeon, and C. W. Kang. 2000. Effects of the pattern of energy supply on the efficiency of nitrogen utilization for microbial protein synthesis in the non-lactating cows consuming grass silage. Asian-australas. J. Anim. Sci. 13:962-966.

Kim, K. H., Y. G. Oh, J. J. Choung, and D. G. Chamberlain. 1999a Effects of varying degrees of synchrony of energy and nitrogen release in the rumen on the synthesis of microbial protein in cattle consuming grass silage. J. Sci. Food Agric. 79:833-838.

Leng, R. A. 1970. Formation and production of volatile fatty acids in the rumen. Pages 406-421 in Physiology of Digestion and Metabolism in the Ruminant. A. T. Phillipson, ed. Oriel Press, Newcastle upon Tyne, UK.

McDonald, P., A. R. Henderson, and S. J. E. Heron. 1991. The Biochemistry of Silage. J. Wiley and Sons, New York, NY.

Muck, R. E. 1987. Dry matter level effects on alfalfa silage quality. 1. Nitrogen transformations. Trans. ASAE 30:7-14.

Murphy, J. J. 1999. The effects of increasing the proportion of molasses in the diet of milking dairy cows on milk production and composition. Anim. Feed Sci. Technol. 78:189-198.

Nagel, S. A., and G. A. Broderick. 1992. Effect of formic acid or formaldehyde treatment of alfalfa silage on nutrient utilization by dairy cows. J. Dairy Sci. 75:140-154.

National Research Council. 1996. Nutrient Requirements of Beef Cattle. 7th rev. ed. National Academy Press, Washington, DC.

National Research Council. 2001. Nutrient Requirements of Dairy Cattle. 7th rev. ed. National Academy Press, Washington, DC.

Obispo, N. E., and B. A. Dehority. 1999. Feasibility of using total purines as a marker for ruminal bacteria. J. Anim. Sci. 77:30843095.

Oser, B. L. 1965. Hawk's Physiological Chemistry. 14th ed. McGrawHill, New York, NY.

Owens, V. N., K. A. Albrecht, R. E. Muck, and S. H. Duke. 1999. Protein degradation and fermentation characteristics of red clover and alfalfa silage harvested with varying levels of total nonstructural carbohydrates. Crop Sci. 39:1873-1880.
Prins, R. A. 1977. Biochemical activities of gut micro-organisms. Pages 73-183 in Microbial Ecology of the Gut. R.T.J. Clarke and T. Bauchop, ed. Academic Press, New York.

Reynal, S. M., G. A. Broderick, S. Ahvenjarvi, and P. Huhtanen. 2003. Effect of feeding protein supplements of differing degradability on omasal flow of microbial and undegraded protein. J. Dairy Sci. 86:1292-1305.

Reynal, S. M., and G. A. Broderick. 2003. Effects of feeding dairy cows protein supplements of varying ruminal degradability. J. Dairy Sci. 86:835-843.

Reynal, S. M., and G. A. Broderick. 2009. A new HPLC purine assay for quantifying microbial flow. J. Dairy Sci. accepted.

Roth, M. 1971. Fluorescence reaction of amino acids. Anal. Chem. $43: 880-882$

Sannes, R. A., M. A. Messman, and D. B. Vagnoni. 2002. Form of rumen-degradable carbohydrate and nitrogen on microbial protein synthesis and protein efficiency of dairy cows. J. Dairy Sci. 85:900-908.

SAS Institute. 1999-2000. SAS/STAT User's Guide. Release 8.1. SAS Inst. Inc., Cary, NC.

Siddons, R. C., J. Paradine, D. E. Beever, and P. R. Cornell. 1985. Ytterbium acetate as a particulate-phase digesta-flow marker. Br. J. Nutr. 54:509-519.

Sklan, D., R. Ashkenazi, A. Braun, A. Devorn, and K. Tabori. 1992. Fatty acids, calcium soaps of fatty acids, and cottonseeds fed to high yielding cows. J. Dairy Sci. 75:2463-2472.

Stokes, S. R., W. H. Hoover, T. K. Miller, and R. P. Manski. 1991. Impact of carbohydrate and protein levels on bacterial metabolism in continuous culture. J. Dairy Sci. 74:860-870.

Sutton, J. D., R. H. Phipps, S. B. Cammell, and D. J. Humphries. 2001. Attempts to improve the utilization of urea-treated wholecrop wheat by lactating dairy cows. Anim. Sci. (Pencaitland) 73:137-147.

Tyrrell, H. F., and J. T. Reid. 1965. Prediction of the energy value of cows' milk. J. Dairy Sci. 48:1215-1233.

Uden, P., P. E. Colucci, and P. J. van Soest. 1980. Investigation of chromium, cerium and cobalt as markers in digesta. Rate of passage studies. J. Sci. Food Agric. 31:625-632.

Vagnoni, D. B., G. A. Broderick, M. K. Clayton, and R. D. Hatfield. 1997. Excretion of purine derivatives by Holstein cows abomasally infused with incremental amounts of purines. J. Dairy Sci. 80:1695-1702.

Valadares, R. F. D., G. A. Broderick, S. C. Valadares Filho, and M. K. Clayton. 1999. Effect of replacing alfalfa silage with high moisture corn on ruminal protein synthesis estimated from excretion of total purine derivatives. J. Dairy Sci. 82:2686-2696.

Vallimont, J. E., F. Bargo, T. W. Cassidy, N. D. Luchini, G. A Broderick, and G. A. Varga. 2004. Effects of replacing dietary starch with sucrose on ruminal fermentation and nitrogen metabolism in continuous culture. J. Dairy Sci. 87:4221-4229.

Van Soest, P. J., J. B. Robertson, and B. A. Lewis. 1991. Methods for dietary fiber, neutral detergent fiber and nonstarch polysaccharides in relation to animal nutrition. J. Dairy Sci. 74:3583-3597.

Vogels, G. D., and C. van der Grift. 1970. Differential analyses of glyoxylate derivatives. Anal. Biochem. 33:143-157.

Weiss, W. P., G. R. Fisher, and G. M. Erickson. 1989. Effect of source of neutral detergent fiber and starch on nutrient utilization by dairy cows. J. Dairy Sci. 72:2308-2315.

Wing, J. M., H. H. Van-Horn, S. D. Sklare, and B. Harris Jr. 1988. Effects of citrus molasses distillers solubles and molasses on rumen parameters and lactation. J. Dairy Sci. 71:414-420. 